\title{
Minute Times Milligram per Milliliter per Kilogram per Meter Squared
}

National Cancer Institute

\section{Source}

National Cancer Institute. Minute Times Milligram per Milliliter per Kilogram per Meter

Squared. NCI Thesaurus. Code C111262.

Minutes times milligrams per milliliter, divided by kilograms per meter squared. 